Copyright $\mathbb{C}$ 1994, International Union of Microbiological Societies

\title{
Lactobacillus kefirgranum sp. nov. and Lactobacillus parakefir sp. nov., Two New Species from Kefir Grains
}

\author{
S. TAKIZAWA, ${ }^{1}$ S. KOJIMA, ${ }^{1}$ S. TAMURA, ${ }^{1}$ S. FUJINAGA, ${ }^{1}$ Y. BENNO, ${ }^{2 *}$ AND T. NAKASE ${ }^{2}$
}

Central Research Laboratory, Glico Dairy Co., Ltd., Akishima, Tokyo 196, ${ }^{1}$ and Japan Collection of Microorganisms, The Institute of Physical and Chemical Research (RIKEN), Wako, Saitama 351-01, Japan

\begin{abstract}
Twelve strains of homofermentative lactobacilli and two strains of heterofermentative lactobacilli were isolated from kefir grains by using R-CW agar medium. The physiological and biochemical characteristics, DNA guanine-plus-cytosine contents, and levels of DNA-DNA relatedness of these isolates and previously described lactobacilli were compared. Our results indicated that two new species, Lactobacillus kefirgranum and Lactobacillus parakefir, could be distinguished. The type strain of $L$. kefirgranum sp. nov. is GCL 1701 (= JCM 8572), and the type strain of L. parakefir sp. nov. is GCL 1731 (= JCM 8573).
\end{abstract}

The microorganisms in kefir grains have been studied by many workers $(6,11,14,16-18)$. Kandler and Kunath (7) described Lactobacillus kefir, a new species of heterofermentative lactobacilli isolated from kefir grains and kefir. Toba et al. (21) developed a medium for isolation of bacteria which produce a capsular polysaccharide that previously had been named kefiran by Kooiman (10) and La Riviere and Kooiman (11). Fujisawa et al. (4) also studied bacteria isolated from kefir grains and described a new species, Lactobacillus kefiranofaciens. The fact that there have been many studies shows

\section{MATERIALS AND METHODS}

Bacterial strains. Twelve homofermentative strains and two heterofermentative strains were isolated from kefir grains obtained from E. C. Hansen's Laboratory in Copenhagen, Denmark. Reference Lactobacillus strains were obtained from the Japan Collection of Microorganisms, Institute of Physical and Chemical Research (RIKEN), Wako-shi, Saitama, Japan.

Isolation of bacteria from kefir grains. Active kefir grains were rinsed and diluted with sterile anaerobic diluting solution

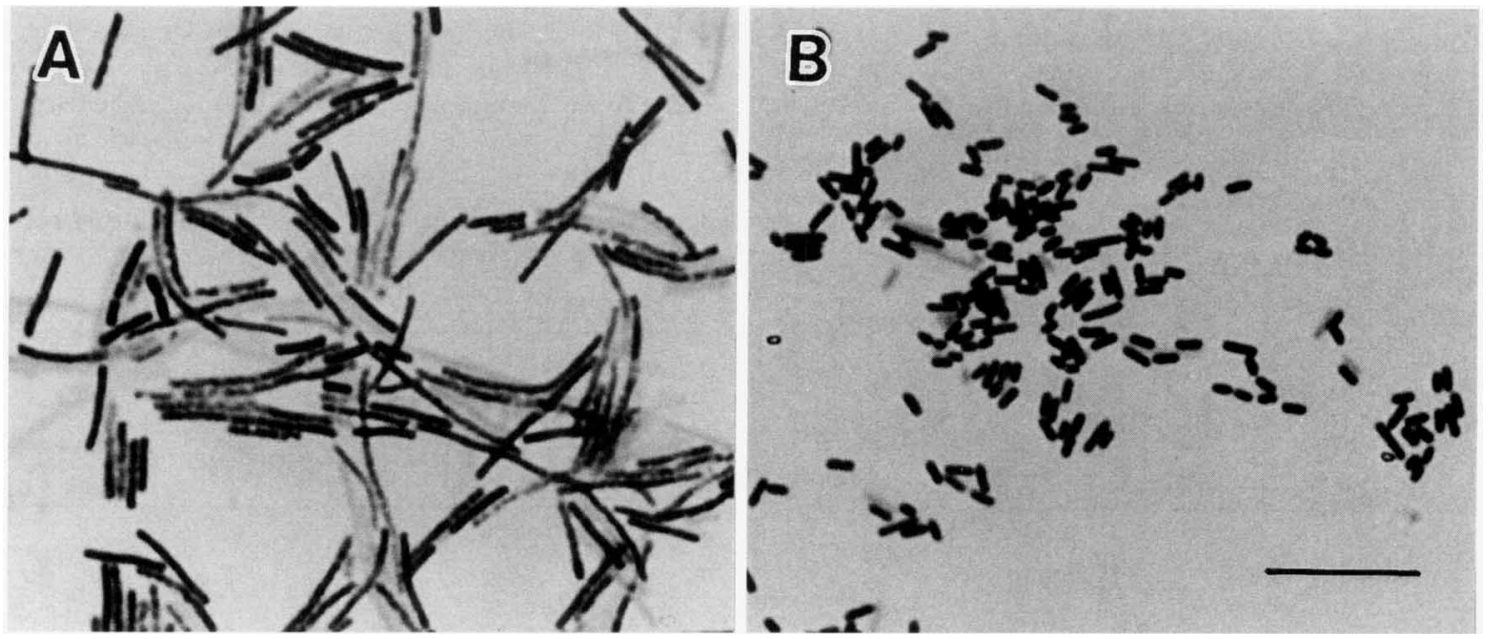

FIG. 1. Photomicrographs of two new species of the genus Lactobacillus isolated from kefir grains and grown on R-CW agar. (A) L. kefirgranum GCL $1701^{\mathrm{T}}$. (B) L. parakefir GCL $1731^{\mathrm{T}}$. Bar $=10 \mu \mathrm{m}$.

that the taxonomic relationships among bacterial species in kefir grains have not been investigated completely.

In this paper, we describe the characteristics of bacteria isolated from kefir grains on R-CW medium (9) and propose two new species, Lactobacillus kefirgranum and Lactobacillus parakefir.

\footnotetext{
* Corresponding author. Mailing address: Japan Collection of Microorganisms, The Institute of Physical and Chemical Research (RIKEN), Wako, Saitama 351-01, Japan. Phone: +81 483621111. Fax: +81 48462 4619. Electronic mail address: benno@viola. riken.go.jp.
}

and homogenized with a Teflon homogenizer. Diluted homogenates were plated on R-CW agar (9) and incubated at $30^{\circ} \mathrm{C}$ for 5 days in an atmosphere containing $100 \% \mathrm{CO}_{2}$. The strains that grew on the plates were subcultured to obtain pure-colony growth and were stored at $-80^{\circ} \mathrm{C}$ after they were subcultured in R-CW broth.

Culture conditions. The strains isolated from kefir grains were cultured on R-CW agar and in R-CW broth at $30^{\circ} \mathrm{C}$ in an atmosphere containing $100 \% \mathrm{CO}_{2}$. The reference strains were cultured on MRS agar and in MRS broth (2).

Determination of taxonomic characteristics. Cell shape, cell size, cell arrangement, the Gram stain reaction, the India 


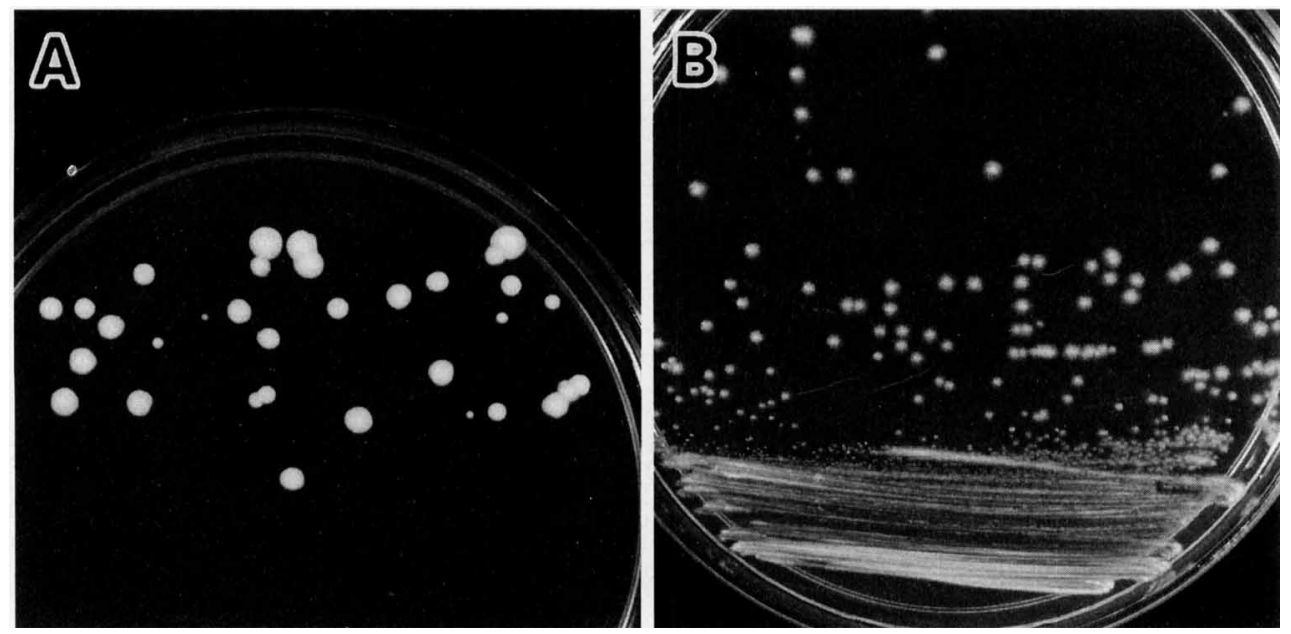

FIG. 2. Colony morphology of two new species of the genus Lactobacillus isolated from kefir grains and grown at $30^{\circ} \mathrm{C}$ for 5 days on R-CW agar. (A) L. kefirgranum GCL $1701^{\mathrm{T}}$. (B) L. parakefir GCL $1731^{\mathrm{T}}$.

ink-staining properties, and colonial appearance were determined by using cells grown on R-CW agar plates for 5 days at $30^{\circ} \mathrm{C}$.

To determine acid production from carbohydrates, R-CW broth (in which lactose in cheese whey was digested by Candida kefyr GCL 5401) was used as the basal medium. The carbon sources were added to the sterile basal medium as filtersterilized solutions to a final concentration of $0.5 \%$. The $\mathrm{pH}$ of each preparation was measured after incubation at $30^{\circ} \mathrm{C}$ for 10 days by using an automatic pH-measuring system (model BIS-120; Lifetec Co., Ltd., Saitama, Japan). Production of gas from glucose and gluconate was examined with Durham tubes.
Hydrolysis of esculin, catalase formation, growth at 15 and $45^{\circ} \mathrm{C}$, and motility were tested by methods previously described by Mitsuoka (15), except that lactose-digested R-CW medium was used as the basal medium. To determine production of ammonia from arginine, we used medium containing $10 \mathrm{~g}$ of L-arginine monohydrochloride, $0.5 \mathrm{~g}$ of tryptone (Difco), $0.5 \mathrm{~g}$ of Trypticase (BBL), $5 \mathrm{~g}$ of sodium chloride, $0.3 \mathrm{~g}$ of $\mathrm{KH}_{2} \mathrm{PO}_{4}$, $0.01 \mathrm{~g}$ of phenol red, $3 \mathrm{~g}$ of Bacto Agar (Difco) and 1,000 ml of cheese whey.

An F-Kit with L-lactate and D-lactate dehydrogenases (Boehringer Mannheim Yamanouchi Ltd., Tokyo, Japan) was used to determine $\mathrm{L}-(+)$ - and $\mathrm{D}-(-)$-lactic acids.

TABLE 1. Biochemical and physiological characteristics of $L$. kefirgranum sp. nov. and L. parakefir sp. nov. isolated from kefir grains ${ }^{a}$

\begin{tabular}{|c|c|c|c|c|c|c|c|c|c|c|c|c|c|c|c|c|c|c|}
\hline \multirow[b]{2}{*}{ Strain } & \multirow[b]{2}{*}{ 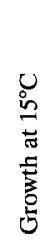 } & \multirow{2}{*}{ 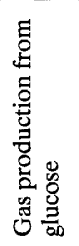 } & \multirow{2}{*}{  } & \multirow{2}{*}{ 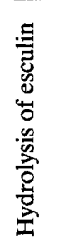 } & \multicolumn{13}{|c|}{ Acid production from: } & \multirow{2}{*}{  } \\
\hline & & & & & 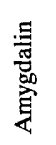 &  & 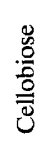 & $\begin{array}{l}\text { 罡 } \\
\text { 品 }\end{array}$ &  & $\begin{array}{l}\text { U. } \\
\text { : } \\
\text { 莺 } \\
\end{array}$ & 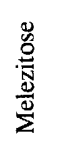 &  & 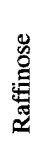 & 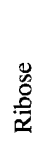 &  & 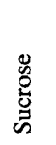 &  & \\
\hline \multicolumn{19}{|c|}{ L. kefirgranum strains ${ }^{c}$} \\
\hline GCL 1701 & w & - & - & + & + & - & + & - & + & + & - & + & + & - & + & + & + & $\mathrm{D}(\mathrm{L})$ \\
\hline GCL 1702 & w & - & - & + & - & - & + & + & + & + & - & + & + & - & + & + & + & $D(L)$ \\
\hline GCL 1703 & w & - & - & + & - & - & + & + & + & + & - & + & + & - & + & + & + & $D(L)$ \\
\hline GCL 1704 & w & - & - & + & - & - & + & - & + & + & - & + & + & - & + & + & + & D \\
\hline GCL $1705^{\mathrm{T}}$ & $\mathrm{w}$ & - & - & + & - & - & + & - & + & + & - & + & + & - & + & + & + & D \\
\hline GCL 1706 & w & - & - & + & - & - & + & - & + & + & - & + & + & - & + & + & - & $D(L)$ \\
\hline GCL 1707 & w & - & - & + & - & - & + & - & + & + & - & + & + & - & - & + & + & $\mathrm{D}(\mathrm{L})$ \\
\hline GCL 1708 & w & - & - & + & - & - & - & - & + & + & - & + & + & - & + & + & + & $\mathrm{D}(\mathrm{L})$ \\
\hline GCL 1709 & w & - & - & + & - & - & - & - & + & + & - & + & + & - & - & + & + & $\mathrm{D}(\mathrm{L})$ \\
\hline GCL 1710 & w & - & - & + & - & - & - & - & + & + & - & + & + & - & + & + & - & $\mathrm{D}(\mathrm{L})$ \\
\hline GCL 1711 & w & - & - & + & - & - & - & - & + & + & - & + & + & - & - & - & - & $D(L)$ \\
\hline GCL 1712 & w & - & - & + & - & - & - & - & + & + & - & + & - & - & - & - & + & L (D) \\
\hline \multicolumn{19}{|c|}{ L. parakefir strains } \\
\hline GCL $1731^{\mathrm{T}}$ & + & + & + & - & - & + & - & - & - & - & + & + & - & + & - & - & - & $\mathrm{L}$ \\
\hline GCL 1732 & + & + & + & - & - & + & - & - & - & - & - & - & - & + & - & - & - & $\mathrm{L}$ \\
\hline
\end{tabular}

\footnotetext{
${ }^{a}+$, positive reaction; - , negative reaction; w, weakly positive reaction. All strains produced acid from galactose, glucose, maltose, and lactose. No acidification occurred on gluconate, mannitol, rhamnose, sorbitol, and xylose. No isolate produced gas from gluconate. No growth occurred at $45^{\circ} \mathrm{C}$.

${ }^{b}$ Based on the content of $\mathrm{L}-(+)$-lactic acid: D, 0 to $20 \% ; \mathrm{D}(\mathrm{L}), 20$ to $40 \%$; L(D), 60 to $80 \% ; \mathrm{L}, 80$ to $100 \%$.

${ }^{c}$ L. kefirgranum GCL 1701, GCL 1703, GCL 1705' , GCL 1708, GCL 1709, and GCL 1712 formed a flocculent sediment. Strains GCL 1702, GCL 1704, GCL 1706, GCL 1707 , GCL 1710 , and GCL 1711 formed a powdery sediment in broth cultures.
} 
TABLE 2. DNA G+C contents and levels of DNA-DNA relatedness for $L$. kefirgranum strains and some reference Lactobacillus strains

\begin{tabular}{|c|c|c|c|c|}
\hline \multirow[b]{2}{*}{ Strain } & \multirow{2}{*}{$\begin{array}{c}\mathrm{G}+\mathrm{C} \\
\text { content } \\
(\mathrm{mol} \%)\end{array}$} & \multicolumn{3}{|c|}{$\%$ DNA-DNA relatedness to: } \\
\hline & & $\begin{array}{l}\text { L. kefirgranum } \\
\text { GCL } 1701^{\mathrm{T}}\end{array}$ & $\begin{array}{c}\text { L. amylovorus } \\
\text { JCM } 1126^{\mathrm{T}}\end{array}$ & $\begin{array}{l}\text { L. helveticus } \\
\text { JCM } 1120^{\mathrm{T}}\end{array}$ \\
\hline \multicolumn{5}{|l|}{ L. kefingranum } \\
\hline GCL $1701^{\mathrm{T}}$ & 38.1 & 100 & 35 & 42 \\
\hline GCL 1702 & 38.1 & 103 & & \\
\hline GCL 1703 & 38.4 & 89 & & \\
\hline GCL 1704 & 37.9 & 111 & & \\
\hline GCL 1705 & 38.6 & 105 & & \\
\hline GCL 1706 & 34.3 & 101 & & \\
\hline GCL 1707 & 37.5 & 100 & & \\
\hline GCL 1708 & 37.4 & 98 & & \\
\hline GCL 1709 & 38.6 & 98 & & \\
\hline GCL 1710 & 37.7 & 104 & & \\
\hline GCL 1711 & 38.2 & 106 & & \\
\hline GCL 1712 & & 106 & & \\
\hline L. acidophilus $\mathrm{JCM} 1132^{\mathrm{T}}$ & 32.6 & 26 & 30 & \\
\hline L. acidophilus JCM 2009 & 34.3 & 38 & & \\
\hline L. amylovorus JCM $1126^{\mathrm{T}}$ & 38.6 & 51 & 100 & 41 \\
\hline L. amylovorus JCM 2010 & 37.1 & 14 & 31 & \\
\hline L. animalis $\mathrm{JCM} 5670^{\mathrm{T}}$ & 39.7 & 2 & & \\
\hline L. crispatus JCM $1185^{\mathrm{T}}$ & 37.0 & 24 & & \\
\hline L. delbrueckii subsp. delbrueckii JCM $1012^{\mathrm{T}}$ & 48.9 & 3 & & \\
\hline L. delbrueckii subsp. lactis JCM $1248^{\mathrm{T}}$ & 50.2 & 5 & & \\
\hline L. delbrueckii subsp. bulgaricus JCM $1002^{\mathrm{T}}$ & 51.6 & 4 & & \\
\hline L. gallinarum JCM $2011^{\mathrm{T}}$ & 35.1 & 13 & 15 & \\
\hline L. gasseri $\mathrm{JCM} 1131^{\mathrm{T}}$ & 34.8 & 10 & 11 & \\
\hline L. helveticus JCM $1120^{\mathrm{T}}$ & 35.5 & 42 & & 100 \\
\hline L. helveticus JCM 1003 & 37.8 & 43 & & 92 \\
\hline L. helveticus JCM 1008 & 37.0 & 32 & & \\
\hline L. jensenii $\mathrm{JCM} 1146^{\mathrm{T}}$ & 42.7 & 5 & & \\
\hline L. johnsonii JCM $2012^{\mathrm{T}}$ & 32.4 & 3 & 5 & \\
\hline L. kefiranofaciens JCM $6985^{\mathrm{T}}$ & 36.0 & 30 & & \\
\hline L. salivarius $\mathrm{JCM} 1231^{\mathrm{T}}$ & 30.4 & 3 & & \\
\hline
\end{tabular}

Cell wall analysis. The presence of diaminopimelic acid isomers in the cell wall was examined by the method of Staneck and Roberts (19).

DNA base composition and DNA-DNA hybridization. DNA was isolated and purified by the method of Marmur (12) by using cells grown for $12 \mathrm{~h}$ in R-CW medium. DNA base composition was calculated from the melting temperature (13) obtained with a spectrophotometer (model DU-8B; Beckman

TABLE 3. DNA G+C contents and levels of DNA-DNA relatedness for $L$. parakefir strains and some reference Lactobacillus strains

\begin{tabular}{|c|c|c|c|}
\hline \multirow[b]{2}{*}{ Strain } & \multirow{2}{*}{$\begin{array}{c}\mathrm{G}+\mathrm{C} \\
\text { content } \\
(\mathrm{mol} \%)\end{array}$} & \multicolumn{2}{|c|}{$\begin{array}{l}\% \text { DNA-DNA } \\
\text { relatedness to: }\end{array}$} \\
\hline & & $\begin{array}{l}\text { L. parakefir } \\
\text { GCL } 1731^{T}\end{array}$ & $\begin{array}{c}\text { L. kefir } \\
\text { JCM } \\
5818^{\mathrm{T}}\end{array}$ \\
\hline \multicolumn{4}{|l|}{ L. parakefir } \\
\hline GCL $1731^{\mathrm{r}}$ & 42.0 & 100 & 35 \\
\hline GCL 1732 & 41.4 & 100 & \\
\hline L. brevis $\mathrm{JCM} 1059^{\mathrm{T}}$ & 45.0 & 4 & \\
\hline L. buchneri JCM $1115^{\mathrm{T}}$ & 42.7 & 36 & \\
\hline L. collinoides $\mathrm{JCM} 1123^{\mathrm{T}}$ & 44.7 & 16 & \\
\hline L. fermentum JCM $1173^{\mathrm{T}}$ & 49.4 & 7 & \\
\hline L. hilgardii JCM $1155^{\mathrm{T}}$ & 39.1 & 29 & \\
\hline L. kefir JCM $5818^{\mathrm{T}}$ & 39.7 & 38 & 100 \\
\hline L. malefermentans $\mathrm{JCM} 1167^{\mathrm{T}}$ & 39.9 & 25 & \\
\hline L. reuteri JCM $1112^{\mathrm{T}}$ & 38.0 & 39 & \\
\hline
\end{tabular}

Instruments, Inc., Fullerton, Calif.). DNA from calf thymus ( $\mathrm{G}+\mathrm{C}$ content, $42 \mathrm{~mol} \%$ ) was used as the reference DNA. DNA-DNA hybridization experiments were performed by using the procedure described by Suzuki et al. (20). DNAs were labeled with a model 5500 nick translation kit (Amersham).

\section{RESULTS}

Morphology of the isolates. The cells of all of the isolates obtained from kefir grains were gram-positive, nonmotile, non-spore-forming rods. These cells occurred singly, in pairs, or occasionally in short chains (Fig. 1). After incubation on R-CW agar plates for 5 days, colonies of $L$. kefingranum were 0.5 to $3.0 \mathrm{~mm}$ in diameter, circular to irregular, convex, opaque, smooth to rough, and white, and colonies of $L$. parakefir were 0.5 to $2.0 \mathrm{~mm}$ in diameter, circular to irregular, flat, opaque, and white (Fig. 2).

Biochemical and physiological characteristics. Characteristics of the isolates are shown in Table $1 . L$. kefirgranum was similar to species belonging to the Lactobacillus acidophilus group, such as Lactobacillus gallinarum and Lactobacillus johnsonii, with respect to $\mathrm{G}+\mathrm{C}$ content and physiological characteristics, but did not grow in the presence of $4 \% \mathrm{NaCl}$. L. parakefir was similar to Lactobacillus brevis, Lactobacillus buchneri, Lactobacillus parabuchneri, and L. kefir in its pattern of acid production from carbohydrates, but differed from these taxa by producing the $\mathrm{L}-(+)$ isomer of lactic acid and by not fermenting gluconate.

Chemotaxonomic characteristics. The isolates which we 
TABLE 4. Phenotypic characteristics that differentiate $L$. kefirgranum sp. nov. and $L$. parakefir sp. nov. from closely related Lactobacillus species ${ }^{a}$



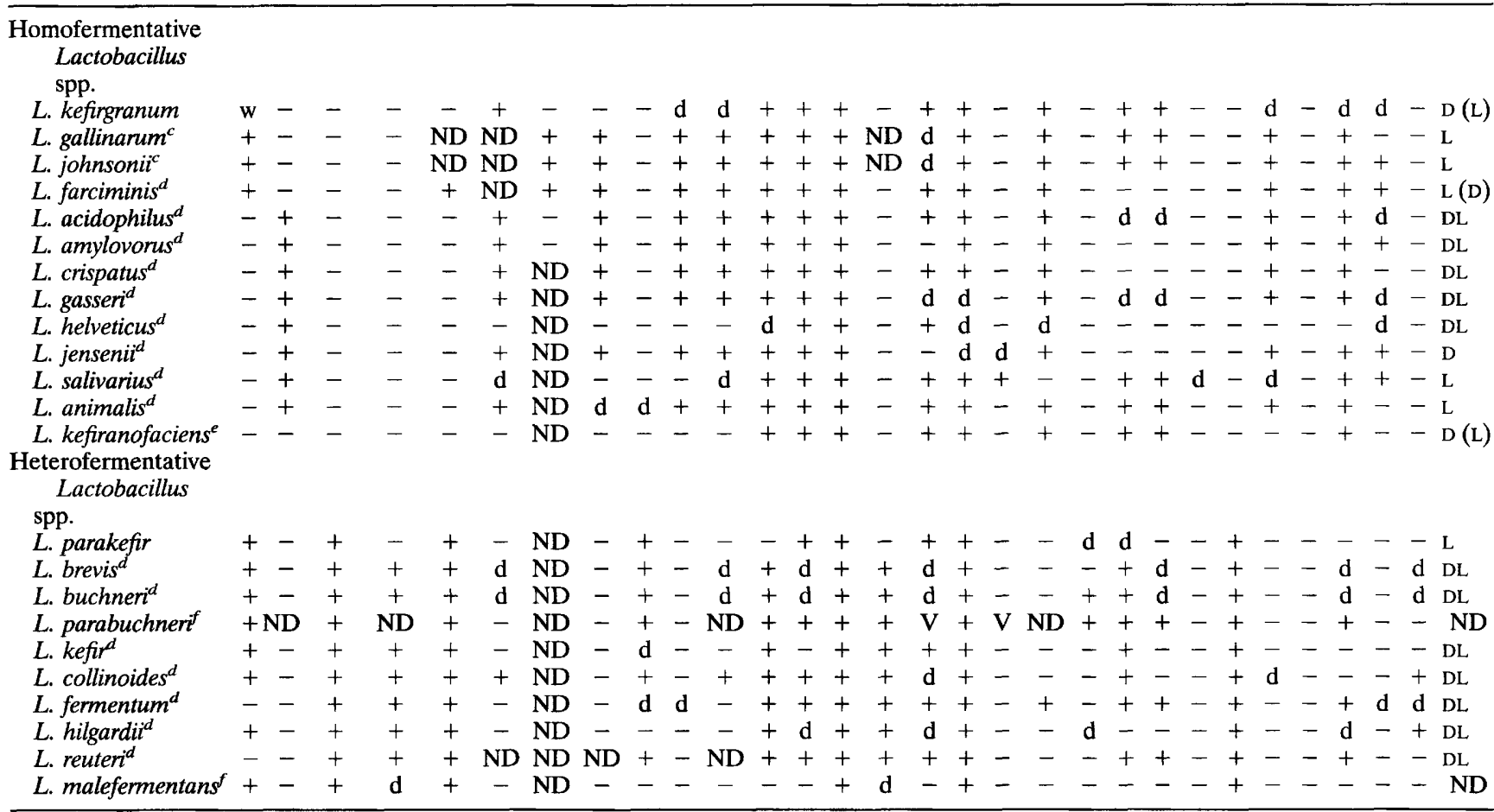

${ }^{a}+, 90 \%$ or more of the strains are positive;,$- 90 \%$ or more of the strains are negative; $\mathrm{d}, 11$ to $89 \%$ of the strains are positive; ND, not done; $\mathrm{V}$, variable reaction; w, weak reaction.

${ }^{b}$ Based on the content of L- $(+)$-lactic acid: D, 0 to $20 \%$; D(L), 20 to $40 \%$; DL, 40 to $60 \%$; L(D), 60 to $80 \%$; L, 80 to $100 \%$.

${ }^{c}$ Data from reference 5 .

${ }^{d}$ Data from reference 8.

$e$ Data from reference 4 .

${ }^{f}$ Data from reference 3 .

studied did not contain diaminopimelic acid isomers. This indicates that $L$. parakefir, which produces $\mathrm{L}-(+)$-lactic acid, also differs from Carnobacterium spp. (1), which contain mesodiaminopimelic acid.

DNA base composition and DNA-DNA hybridization. Tables 2 and 3 show the $\mathrm{G}+\mathrm{C}$ contents and DNA-DNA hybridization data for the isolates which we studied and some reference species. L. kefirgranum GCL $1701^{\mathrm{T}}(\mathrm{T}=$ type strain) exhibited high levels of DNA relatedness to all other strains of $L$. kefirgranum, but little or no relatedness to reference strains. The level of DNA relatedness between $L$. parakefir GCL $1731^{\mathrm{T}}$ and strain GCL 1732 was $100 \%$, whereas all of the reference Lactobacillus strains used for comparison exhibited only very low levels of relatedness to L. parakefir GCL $1731^{\mathrm{T}}$.

\section{DISCUSSION}

The morphological, biochemical, and physiological characteristics of the strains isolated from kefir grains indicate that these organisms belong to the genus Lactobacillus (8). DNA hybridization experiments revealed two separate genotypic groups among the isolates obtained from kefir grains when they were compared with authentic strains of lactobacilli having similar DNA base compositions. All of the previously described strains which we studied exhibited relatively low levels of DNA relatedness to the isolates obtained in this study.

On the basis of our results, we propose that the isolates obtained from kefir grains should be placed in the following two new species of the genus Lactobacillus: Lactobacillus kefingranum, a homofermentative Lactobacillus species; and Lactobacillus parakefir, a heterofermentative Lactobacillus species. The characteristics that differentiate these new species from $L$. acidophilus, Lactobacillus amylovorus, Lactobacillus helveticus, and L. kefiranofaciens are shown in Table 4.

Description of Lactobacillus kefirgranum sp. nov. Lactobacillus kefirgranum (ke.fir.gra'num. Turkish n. kefir, Caucasian sour milk; L. n. granum, grain; M.L. adj. kefirgranum, kefir grain). Cells are gram-positive, nonmotile, non-spore-forming rods that are generally 0.5 to 1.2 by 5.0 to $15.0 \mu \mathrm{m}$ and occur singly, in pairs, or occasionally in short chains. When the organism is grown on R-CW agar at $30^{\circ} \mathrm{C}$ for 5 days, colonies are 0.5 to $3.0 \mathrm{~mm}$ in diameter, circular to irregular, convex, 
opaque, white, and smooth to rough. There is no growth at $45^{\circ} \mathrm{C}$, and weak growth occurs at $15^{\circ} \mathrm{C}$.

Facultatively anaerobic, producing DL-lactic acid homofermentatively. Hydrogen sulfide, catalase, and oxidase are not produced. Esculin is hydrolyzed by almost all strains. Arginine is not deaminated. No gas is produced from glucose or gluconate. Milk is curdled. Acid is produced from galactose, glucose, fructose, lactose, maltose, mannose, and melibiose but not from L-arabinose, gluconate, mannitol, melezitose, L-rhamnose, D-ribose, sorbitol, and D-xylose. Acid production from amygdalin, cellobiose, esculin, raffinose, salicin, sucrose, and trehalose varies with the strain.

The DNA $\mathrm{G}+\mathrm{C}$ content is 34.3 to $38.6 \mathrm{~mol} \%$; the DNA $\mathrm{G}+\mathrm{C}$ content of the type strain is $38.1 \mathrm{~mol} \%$. The habitat is kefir grains.

The type strain is strain GCL 1701 (= JCM 8572).

Description of Lactobacillus parakefir sp. nov. Lactobacillus parakefir (pa.ra.ke'fir. Gr. prep. para, resembling; M.L. n. kefir, the specific epithet of L. kefir; M.L.adj. parakefir, resembling $L$. $k e f i r)$. Cells are gram-positive, nonmotile, non-spore-forming rods that are generally 0.5 to 1.2 by 1.0 to $3.5 \mu \mathrm{m}$ and occur singly, in pairs, or occasionally in short chains. When the organism is grown on R-CW agar at $30^{\circ} \mathrm{C}$ for 5 days, colonies are 0.5 to $2.0 \mathrm{~mm}$ in diameter, circular to irregular, flat, opaque, white, and rough. There is no growth at $45^{\circ} \mathrm{C}$, and good growth occurs at $15^{\circ} \mathrm{C}$.

Facultatively anaerobic. Produces L-lactic acid and $\mathrm{CO}_{2}$ by heterofermentation. Hydrogen sulfide, catalase, and oxidase are not produced. Arginine is deaminated. Esculin is not hydrolyzed. Gas is produced from glucose, but not from gluconate. Milk is curdled.

Acid is produced from L-arabinose, galactose, glucose, lactose, maltose, and D-ribose but not from amygdalin, cellobiose, esculin, fructose, gluconate, mannose, mannitol, raffinose, Lrhamnose, salicin, sorbitol, sucrose, trehalose, and D-xylose. Acid production from melezitose and melibiose varies with the strain.

The DNA G+C content is 41.4 to $42.0 \mathrm{~mol} \%$; the DNA $\mathrm{G}+\mathrm{C}$ content of the type strain is $42.0 \mathrm{~mol} \%$. The habitat is kefir grains.

The type strain is strain GCL 1731 (= JCM 8573).

\section{REFERENCES}

1. Collins, M. D., J. A. E. Farrow, B. A. Phillips, S. Ferusu, and D. Jones. 1987. Classification of Lactobacillus divergens, Lactobacillus piscicola, and some catalase-negative, asporogenous, rod-shaped bacteria from poultry in a new genus, Camobacterium. Int. J. Syst. Bacteriol. 37:310-316.

2. DeMan, J. C., M. Rogosa, and M. E. Sharpe. 1960. A medium for the cultivation of lactobacilli. J. Appl. Bacteriol. 23:130-135.

3. Farrow, J. A. E., B. A. Phillips, and M. D. Collins. 1986. Nucleic acid studies on some heterofermentative lactobacilli: description of Lactobacillus malefermentans sp. nov. and Lactobacillus parabuchneri sp. nov. FEMS Microbiol. Lett. 55:163-168.

4. Fujisawa, T., S. Adachi, T. Toba, K. Arihara, and T. Mitsuoka. 1988. Lactobacillus kefiranofaciens sp. nov. isolated from kefir grains. Int. J. Syst. Bacteriol. 38:12-14.

5. Fujisawa, T., Y. Benno, T. Yaeshima, and T. Mitsuoka. 1992. Taxonomic study of the Lactobacillus acidophilus group, with recognition of Lactobacillus gallinarum sp. nov. and Lactobacillus johnsonii sp. nov. and synonymy of Lactobacillus acidophilus group A3 (Johnson et al. 1980) with the type strain of Lactobacillus amylovorus (Nakamura 1981). Int. J. Syst. Bacteriol. 42:487-491.

6. Hirota, T., and T. Kikuchi. 1976. Studies on kefir grains. I. Isolation and classification of microorganisms from kefir grains and their characteristics. Rep. Res. Lab. Snow Brand 74:63-82.

7. Kandler, O., and P. Kunath. 1983. Lactobacillus kefir sp. nov., a component of the microflora of kefir. Syst. Appl. Microbiol. 4:286-294.

8. Kandler, O., and N. Weiss. 1986. Genus Lactobacillus Beijerinck 1901, 212 ${ }^{\mathrm{AL}}$, p. 1209-1234. In P. H. A. Sneath, N. S. Mair, M. E. Sharpe, and J. G. Holt (ed.), Bergey's manual of systematic bacteriology, vol. 2. The Williams \& Wilkins Co., Baltimore.

9. Kojima, S., S. Takizawa, S. Tamura, S. Fujinaga, Y. Benno, and T. Nakase. 1993. A new medium for the isolation of lactobacilli from kefir grains. Biosci. Biotechnol. Biochem. 57:119-120.

10. Kooiman, P. 1968. The chemical structure of kefiran, the watersoluble polysaccharide of the kefir grain. Carbohydr. Res. 7:200211.

11. La Riviere, J. W. M., and P. Kooiman. 1967. Kefiran, a novel polysaccharide produced in the kefir grain by Lactobacillus brevis. Arch. Microbiol. 59:269-278.

12. Marmur, J. 1961. A procedure for the isolation of deoxyribonucleic acid from microorganisms. J. Mol. Biol. 3:208-218.

13. Marmur, J., and P. Doty. 1962. Determination of the base composition of deoxyribonucleic acid from its thermal denaturation temperature. J. Mol. Biol. 5:109-118.

14. Marshall, V. M., W. M. Cole, and J. A. E. Farrow. 1984. A note on the heterofermentative Lactobacillus isolated from kefir grains. J. Appl. Bacteriol. 56:503-505.

15. Mitsuoka, T. 1969. Vergleichende Untersuchungen über die Laktobazillen aus den Faeces von Menschen, Schweinen und Hühnern. Zentralbl. Bakteriol. Parasitenkd. Infektionskr. Hyg. Abt. 1 Orig. 210:32-51.

16. Rosi, J. 1978. The kefir microorganisms: the acetic acid bacteria. Sci. Tech. Lattiero Casearia 29:221-227.

17. Rosi, J. 1978. The kefir microorganisms: the yeasts. Sci. Tech. Lattiero Casearia. 29:59-67.

18. Rosi, J., and J. Rossi. 1978. The kefir microorganisms: the lactic acid bacteria. Sci. Tech. Lattiero Casearia 29:291-305.

19. Staneck, J. L., and G. D. Roberts. 1974. Simplified approach to identification of aerobic actinomycetes by thin-layer chromatography. Appl. Microbiol. 28:226-231.

20. Suzuki, K., T. Kaneko, and K. Komagata. 1981. Deoxyribonucleic acid homologies among coryneform bacteria. Int. J. Syst. Bacteriol. 31:131-138.

21. Toba, T., S. Abe, K. Arihara, and S. Adachi. 1986. A medium for the isolation of capsular bacteria from kefir grains. Agric. Biol. Chem. 50:2673-2674. 